\title{
Potencjalne możliwości wykorzystania berberyny w przeciwdziałaniu insulinooporności i w cukrzycy typu 2
}

Potential berberine effect in the insulin resistance prevention and type 2 diabetes treatment

Michalina Mróz ${ }^{1}$ Katarzyna Pastusiak², Paweł Bogdański²

'Studenckie Koło Naukowe Dietetyki Klinicznej, Uniwersytet Medyczny im. Karola Marcinkowskiego w Poznaniu

${ }^{2}$ Katedra i Zakład Leczenia Otyłości, Zaburzeń Metabolicznych i Dietetyki Klinicznej, Uniwersytet Medyczny im. Karola Marcinkowskiego w

Poznaniu

\section{Abstrakt}

Insulinooporność to stan zmniejszonej wraźliwości tkanek docelowych na działanie insuliny, mimo jej prawidłowego lub podwyższonego stężenia w surowicy krwi. Jest ważnym czynnikiem w patogenezie zespołu metabolicznego, w tym stanu przedcukrzycowego i cukrzycy typu 2, a także chorób sercowo-naczyniowych oraz zespołu policystycznych jajników. Wzrasta zainteresowanie wykorzystaniem środków pochodzenia roślinnego w leczeniu pacjentów z chorobami metabolicznymi. Jednymi z nich są rośliny z rodziny berberysowatych zawierające alkaloidy izochinolinowe, takie jak berberyna. Sugeruje się, iż berberyna może wpływać na zmniejszenie insulinooporności, gospodarkę węglowodanową oraz metabolizm lipidów. Naukowcy wykazali, że ten roślinny alkaloid może tłumić różnicowanie adipocytów i wspomagać redukcję masy ciała. Inne właściwości berberyny obejmują działanie hipotensyjne oraz ochronne wobec śródbłonka naczyniowego. W artykule skoncentrowano się przede wszystkim na przedstawieniu potencjalnych możliwości wykorzystania berberyny w przeciwdziałaniu insulinooporności w cukrzycy typu 2.

Słowa

berberyna • insulinooporność • cukrzyca typu 2・ zespół metaboliczny• hiperglikemia

Otrzymano: 30.10.2020, Zaakceptowano: 14.07.2021

Abstract

Insulin resistance is a state of decreased sensitivity of target tissues to the action of insulin, despite its normal or increased concentration in blood serum. It is a significant factor in the pathogenesis of the metabolic syndrome, including pre-diabetes and type 2 diabetes, as well as cardiovascular diseases and polycystic ovary syndrome. Nowadays, interest in the use of plant-based agents in the treatment of metabolic diseases is constantly increasing. One of these agents are plants from the barberry family containing isoquinoline alkaloids such as berberine. Current scientific evidence suggests that berberine may have a positive effect on the reduction of insulin resistance, carbohydrate metabolism and lipid metabolism. Scientists have shown that this plant alkaloid could suppress adipocyte differentiation and promote weight reduction. Other effects of berberine include a hypotensive effect and a protective on the vascular endothelium. This review largely focuses on presenting the potential use of berberine in the prevention of insulin resistance and treatment of type 2 diabetes.

Keywords

berberine $\bullet$ insulin resistance $\bullet$ type 2 diabetes $\bullet$ metabolic syndrome $\bullet$ hyperglycemia

Received: 30.10 .2020 , Accepted: 14.07.2021

*Corresponding author e-mail: michalina.mroz@gmail.com

(c) BY-NC-ND (c) 2021 Mróz et al., This work is licensed under the Creative Commons Attribution-NonCommercial-NoDerivs 4.0 License. 
Berberyna (berberine, BBR), alkaloid izochinolinowy, należy do naturalnie występującej klasy protoberberyn. Znajduje się w roślinach z rodziny Berberidaceae (berberysowate), Papaveraceae (makowate) i Ranunculaceae (jaskrowate), w tym Arcangelisia flava, Berberis vulgaris (berberys pospolity, berberys zwyczajny), $B$. aristata (berberys indyjski, kurkuma drzewna), B. Iycium, B. crataegi, Mahonia aquifolium (mahonia pospolita, mahonia ostrolistna, ościał pospolity), Hydrastis canadensis (gorzknik kanadyjski) i Coptis chinensis (cynowód chiński). Zawartość BBR w liściach i korzeniu B. vulgaris wynosi $1,5-2 \%$. Prawdopodobnie jest wchłaniana $\mathrm{z}$ przewodu pokarmowego, jednak jej biodostępność po podaniu doustnym jest niewielka. Przemiana $\mathrm{w}$ postać zjonizowaną zachodzi $\mathrm{w}$ warunkach fizjologicznych, a samoagregacja przy niskim pH. Badania wskazują, iż BBR jest przekształcana przez mikrobiotę jelitową do postaci dihydroberberyny, która cechuje się znacznie lepszą wchłanialnością. Dystrybucja tego alkaloidu odbywa się w wątrobie, nerkach, mięśniach, płucach, mózgu, sercu, trzustce oraz tkance tłuszczowej. W metabolizmie wątrobowym, przez oksydacyjną demetylację i glukuronidację, powstaje berberrubina, talalifendina, demetylenoberberyna i jatroryzyna oraz ich formy glukoronidowe. CYP2D6, CYP1A2, CYP3A4, CYP2E1 i CYP2C19 to główne cytochromy biorące udział w metabolizmie BBR. Jej metabolity są wydalane $z$ kałem, moczem i żółcią. Prawdopodobnie BBR wchodzi w interakcje $z$ metforminą (metformin, MET), ketokonazolem, digoksyną i cyklosporyną $\mathrm{A}, \mathrm{w}$ związku z czym należy zachować szczególną ostrożność podczas jednoczesnego podawania tych preparatów. Kobiety w ciąży, karmiące piersią oraz małe dzieci powinny unikać jej stosowania. Toksyczność $B$. vulgaris i BBR zależy od eksperymentalnego gatunku zwierząt, dawki i sposobu podawania, a także źródła substancji. Ryzyko toksyczności po podaniu doustnym jest mniejsze niż iniekcja domięśniowa lub dootrzewnowa. Wyniki badań na zwierzętach i in vitro wykazały, że suplementacja BBR przypuszczalnie wywołuje zaburzenia i owrzodzenia przewodu pokarmowego, immuno-, foto-, neuro- oraz kardiotoksyczność w sposób zależny od dawki [1, 2].

Wzrastająca liczba dowodów naukowych sugeruje, iż BBR może się charakteryzować wielokierunkowym działaniem farmakologicznym, m.in. bakteriobójczym, przeciwzapalnym, hipoglikemicznym, hipotensyjnym, hipocholesterolemicznym, a nawet przeciwnowotworowym. Ponadto substancja ta wykazuje korzystny wpływ na insulinooporność (insulin resistance, IR), gospodarkę węglowodanową oraz metabolizm lipidów [1].

Korzystając $z$ baz danych PubMed oraz Google Scholar z okresu 2010-2020 omówiono piśmiennictwo pod kątem potencjalnego wykorzystania BBR w przeciwdziałaniu IRi cukrzycy typu 2 (type 2 diabetes, T2D).

\section{Wyjaśnienie potencjału zastosowania BBR w IR}

\section{Badania in vitro}

W licznych badaniach przedstawiano mechanizmy działania BBR na poziomie komórkowym, zwłaszcza w komórkach wątroby, adipocytach i miocytach. Wyniki wybranych badań in vitro zestawiono $w$ tabeli 1 .

Glukagonopodobny peptyd 1 (glucagon-like peptide-1, GLP-1) jest silnie zależnym od glukozy insulinotropowym hormonem uwalnianym $z$ jelitowych komórek L. Wywiera istotny wpływ na regulację metabolizmu glukozy, stymulując wydzielanie insuliny, promując proliferację komórek beta, a także hamując uwalnianie glukagonu, opróżnianie żołądka oraz przyjmowanie pokarmu. Wyniki badania in vitro i in vivo wykazały, że BBR moduluje wydzielanie i biosyntezę GLP1 częściowo przez regulację ekspresji genu proglukagonu i konwertazy prohormonu 3. W proces ten są zaangażowane również niektóre ścieżki sygnałowe, w tym szlak zależny od kinazy białkowej C. Wyjaśnienie mechanizmów kontrolujących wydzielanie GLP-1 za pośrednictwem BBR może ułatwić zrozumienie działania przeciwcukrzycowego tego alkaloidu [3]. Efekt hipoglikemiczny BBR występuje także wskutek zwiększenia ekspresji receptora insuliny (insulin receptor, InsR) w różnych liniach komórkowych [4]. Xing i wsp. wskazują, że BBR poprawia insulinowrażliwość w niealkoholowej stłuszczeniowej chorobie wątroby (non alcoholic fatty liver disease, NAFLD) prawdopodobnie przez regulację poziomu substratu receptora insuliny, podstawowej cząsteczki na szlaku sygnałowym insuliny. Wyniki tego badania sugerują, że BBR może mieć zastosowanie w NAFLD [5]. Dane pochodzące z innej pracy badawczej wskazują, że BBR poprawia profil glikemiczny przez bezpośrednie hamowanie glukoneogenezy w wątrobie, prawdopodobnie w wyniku inhibicji mitochondriów. Potwierdza to, że BBR polepsza metabolizm glukozy za pośrednictwem szlaku niezależnego od insuliny [6].

Udowodniono, że etanolowy ekstrakt z korzeni B. vulgaris i chlorek berberyny hamują aktywność alfa-glukozydazy wprost proporcjonalne do ich stężenia. Ponadto działanie było silniejsze dla $B$. vulgaris. BBR, jako potencjalny inhibitor alfa-glukozydazy, skutecznie opóźnia wchłanianie węglowodanów i hamuje poposiłkową hiperglikemię, co przyczynia się do lepszej kontroli T2D [7]. Podobne działanie, w hamowaniu aktywności alfa-amylazy, wykazano dla metanolowego ekstraktu B. vulgaris [8]. Stwierdzono także, że metanolowy ekstrakt z kory kurkumy (B. aristata) może hamować aktywność dipeptydylopeptydazy typu 4, zapobiegając inhibicji GLP-1, a tym samym BBR może być potencjalnym lekiem przeciwcukrzycowym [9]. 
Tabela 1. Wyniki wybranych badań in vitro przedstawiające potencjalne działanie berberyny przeciwko cukrzycy i innym chorobom metabolicznym

\begin{tabular}{|c|c|c|c|c|}
\hline Autor & Rok & Rodzaj badanego materiału & Efekt BBR $(p<0,05)$ & Piśmiennictwo \\
\hline Yu i wsp. & 2010 & $\begin{array}{l}\text { Ludzkie komórki NCl-H716 } \\
1 \mu \mathrm{M}, 10 \mu \mathrm{M} \text {, i } 100 \mu \mathrm{M} \text { BBR, } 2 \mathrm{~h} \\
100 \mu \mathrm{M} \text { BBR, } 24 \mathrm{~h}\end{array}$ & $\begin{array}{c}\uparrow \text { sekrecji GLP-1 } \\
\uparrow \text { ekspresji genu proglukagonu i PC3 }\end{array}$ & [3] \\
\hline Zhang i wsp. & 2010 & $\begin{array}{c}\text { CEM T-limfocyty, HCT-116 komórki raka okrężnicy, SW1990 komórki } \\
\text { trzustki, HT1080 komórki włókniakomięsaka, 293T komórki fibro- } \\
\text { blastów } \\
\text { BBR }(10 \mu \mathrm{g} / \mathrm{mL}), 12 \mathrm{~h}\end{array}$ & $\begin{array}{l}\uparrow \text { ekspresji InsR mRNA we wszystkich } \\
\text { liniach komórkowych }\end{array}$ & {$[4]$} \\
\hline Xing i wsp. & 2011 & $\begin{array}{c}\text { Hepatocyty pochodzące od: } \\
\text { Grupa kontrolna - zdrowe samce szczura Wistar }(\mathrm{n}=10) \\
\text { Szczury z NAFLD - BRR (187.5 mg/kg mc/d), } 4 \text { tygodnie }(\mathrm{n}=10) \\
\text { Szczury z NAFLD - pioglitazon }(10 \mathrm{mg} / \mathrm{kg} \mathrm{mc/d}), 4 \text { tygodnie }(\mathrm{n}=10) \\
\text { Szczury z NAFLD - sól fizjologiczna }(3 \mathrm{ml} / \mathrm{kg} \mathrm{mc} / \mathrm{d}), 4 \text { tygodnie } \\
(\mathrm{n}=10)\end{array}$ & $\begin{array}{c}\downarrow \text { zawartości TG w wątrobie } \\
\downarrow \text { stłuszczenia i stanu zapalnego w } \\
\text { wątrobie } \\
\uparrow \text { ekspresji IRS-2 mRNA }\end{array}$ & {$[5]$} \\
\hline Xia i wsp. & 2011 & $\begin{array}{l}\text { Hepatocyty pochodzące od zdrowych samców szczura Sprague- } \\
\text { Dawley i szczurów z DM indukowaną STZ na HFD; BBR = } 380 \mathrm{mg} / \mathrm{kg} \\
\text { mc/d , } 5 \text { tygodni }(\mathrm{n}=6)\end{array}$ & $\begin{array}{c}\downarrow \text { ekspresji białka FoX01, SREBP1 i } \\
\text { ChREBP } \\
\downarrow \text { ekspresji, PEPCK i G6P-azy } \\
\downarrow \text { FAS } \\
\downarrow \text { akumulacji lipidów w wątrobie }\end{array}$ & [6] \\
\hline $\begin{array}{l}\text { Abd El- } \\
\text { Wahab i wsp. }\end{array}$ & 2013 & $\begin{array}{l}\text { Homogenat wątroby pochodzący od myszy Balb/c }(n=6) \\
\text { Ekstrakt etanolowy z korzeni } B \text {. vulgaris i chlorek berberyny w } \\
\text { stężeniach: } 0.2,0.4,0.6,0.8 \text { i } 1.0 \mathrm{mg} / \mathrm{ml}\end{array}$ & $\begin{array}{c}\downarrow \text { aktywności } \alpha \text {-glukozydazy (przy } \\
\text { czym hamowanie wywołane przez } \\
\text { ekstrakt } B \text {. vulgaris było } \uparrow \text { niż } \\
\text { hamowanie przez chlorek berberyny) }\end{array}$ & [7] \\
\hline $\begin{array}{l}\text { Boudjelthia i } \\
\text { wsp. }\end{array}$ & 2017 & $\begin{array}{l}\text { Metanolowy i wodny ekstrakt B. vulgaris o stężeniach: } 1.6,2.4,3.2 \text {, } \\
\qquad 4.8 \text { i } 6.4 \mathrm{mg} / \mathrm{ml}\end{array}$ & $\begin{array}{c}\downarrow \text { aktywności } \alpha \text {-amylazy (przy } \\
\text { czym hamowanie wywołane przez } \\
\text { metanolowy ekstrakt było } \uparrow \text { niż przez } \\
\text { ekstrakt wodny) }\end{array}$ & [8] \\
\hline $\begin{array}{l}\text { Chakrabarti i } \\
\text { wsp. }\end{array}$ & 2011 & $\begin{array}{l}\text { DPP-4 pochodząca ze świńskiej nerki } \\
\text { Metanolowy ekstrakt z kory } B \text {. aristata o stężeniach: } 2.5,40,80 \mu \mathrm{g} / \mathrm{ml}\end{array}$ & $\downarrow$ aktywności DPP-4 & [9] \\
\hline Jiang i wsp. & 2015 & $\begin{array}{l}\text { Tkanki wątroby pochodzące od samców szczurów Wistar: } \\
\text { Grupa kontrolna - zdrowe szczury }(\mathrm{n}=8) \\
\text { Szczury z DM indukowaną STZ }(\mathrm{n}=8) \\
\text { Szczury z DM indukowaną STZ + BBR }(156 \mathrm{mg} / \mathrm{kg} \mathrm{mc/d}), 12 \text { tygodni } \\
(\mathrm{n}=8)\end{array}$ & $\begin{array}{l}\uparrow \text { ekspresji białka LKB1, AMPK, p- } \\
\text { AMPK i p-TORC2 } \\
\downarrow \text { ekspresji białka PEPCK i G-6-P }\end{array}$ & {$[10]$} \\
\hline $\begin{array}{l}\text { Furrianca i } \\
\text { wsp. }\end{array}$ & 2017 & $\begin{array}{l}\text { Ludzkie komórki wątroby HepG2 } \\
\text { Ekstrakt z korzenia B. microphylla } \\
(10,5,2.5 \text { i } 1.25 \times 10-3 \mu \mathrm{g} / \mu \mathrm{L}), 24 \mathrm{~h} \\
\operatorname{BBR}(0.25 \times 10-3 \mu \mathrm{g} / \mu \mathrm{L}), 24 \mathrm{~h} \\
\operatorname{MET}(0.25 \times 10-3 \mu \mathrm{g} / \mu \mathrm{L}), 24 \mathrm{~h}\end{array}$ & $\begin{array}{l}\uparrow \text { wychwytu glukozy w komórkach } \\
\text { HepG2 z i bez IR } \\
\text { Aktywacja fosforylacji AMPK }\end{array}$ & [11] \\
\hline Xu i wsp. & 2014 & $\begin{array}{l}\text { Ludzkie komórki raka wątroby HepG2 i mysi mioblast szkieletowy } \\
\qquad \begin{array}{l}\text { C2C12 } \\
\operatorname{BBR}(5-40 \mu \mathrm{mol} / \mathrm{L}), 24 \mathrm{~h} \\
\operatorname{MET}(1-10 \mu \mathrm{mol} / \mathrm{L}), 24 \mathrm{~h}\end{array}\end{array}$ & $\begin{array}{c}\text { Hamowanie kompleksu I łańcucha } \\
\text { oddechowego } \\
\downarrow \text { syntezy ATP } \\
\uparrow \text { uwalnianie mleczanu i } \uparrow \text { zużycia } \\
\text { glukozy w sposób zależny od dawki } \\
\uparrow \text { fosforylacji AMPK i syntazy acetylo- } \\
\text { koenzymowej }\end{array}$ & [12] \\
\hline
\end{tabular}




\begin{tabular}{|c|c|c|c|c|}
\hline Autor & Rok & Rodzaj badanego materiału & Efekt BBR $(p<0,05)$ & Piśmiennictwo \\
\hline Zhang i wsp. & 2018 & $\begin{array}{l}\text { Pierwotne hepatocyty pochodzące od dorosłych myszy } \\
\qquad \operatorname{BBR}(0,5,10 \mu \mathrm{M}), 6-8 \mathrm{~h}\end{array}$ & $\begin{array}{c}\text { Hamowanie aktywności kompleksu I } \\
\text { łańcucha oddechowego (dehydroge- } \\
\text { nazy NADH) } \\
\text { A AMP poprzez hamowanie deacety- } \\
\text { lazy SIRT-3 } \\
\uparrow \text { wychwyt glukozy związany z AMPK } \\
\text { inhibicja cyklazy adenylowej } \\
\downarrow \text { poziomu cAMP i aktywności PKA } \\
\text { degradacja enzymu PEPCK1 } \\
\text { blokowanie indukowanej glukagonem } \\
\text { wątrobowej glukoneogenezy }\end{array}$ & [13] \\
\hline Liu i wsp. & 2018 & $\begin{array}{c}\text { Hepatocyty, jelito cienkie } \\
\text { pochodzące od samców szczura Wistar } \\
\text { Grupa kontrolna: zdrowe szczury na NCD }(n=10) \\
\text { Otyłe szczury na HFD + BBR: } 200 \mathrm{mg} / \mathrm{kg} \mathrm{mc} / \mathrm{d}, 8 \text { tygodni }(\mathrm{n}=10) \\
\text { Otyłe szczury na HFD + woda destylowana, } 8 \text { tygodni }(\mathrm{n}=10)\end{array}$ & $\begin{array}{c}\uparrow \text { Bifidobacterium, Lactobacillus, } \\
\downarrow \text { Escherichia coli, Enterococcus spp. } \\
\text { w jelicie } \\
\downarrow \text { TLR4, TNF-a w wątrobie } \\
\uparrow \text { InsR i IRS-1 mRNA w wątrobie }\end{array}$ & [14] \\
\hline Zhong i wsp. & 2020 & $\begin{array}{l}\text { Hepatocyty pochodzące od: } \\
\text { Myszy ob/ob i myszy C57BI/6J z DM indukowaną STZ } \\
\text { BBR }(0-10 \mu \mathrm{M})\end{array}$ & $\begin{array}{c}\downarrow \text { PEPCK, G6P-azy i PGC1a } \\
\downarrow \text { fosforylacji CREB u myszy ob/ob } \\
\downarrow \text { podstawowej i indukowanej glu- } \\
\text { kagonem produkcji glukozy } \\
\downarrow \text { cAMP i bromo-cAMP } \\
\downarrow \text { fosforylacji CREB stymulowanej } \\
\text { forskoliną }\end{array}$ & [15] \\
\hline Liu i wsp. & 2010 & $\begin{array}{l}\text { Ludzkie komórki Caco-2 cells pochodzące od gruczolakoraka jelita } \\
\text { grubego } \\
\qquad \begin{array}{c}\text { BBR }(2,10,50 \mu \mathrm{M}), 5 \mathrm{dni} \\
\text { Akarboza }(50 \mu \mathrm{M}), 5 \mathrm{dni}\end{array}\end{array}$ & $\begin{array}{l}\downarrow \text { aktywności disacharydaz (sacharazy } \\
\text { i maltazy) } \\
\downarrow \text { ekspresji kompleksu sacharaza- } \\
\text { izomaltazy mRNA }\end{array}$ & [16] \\
\hline Gong i wsp. & 2017 & 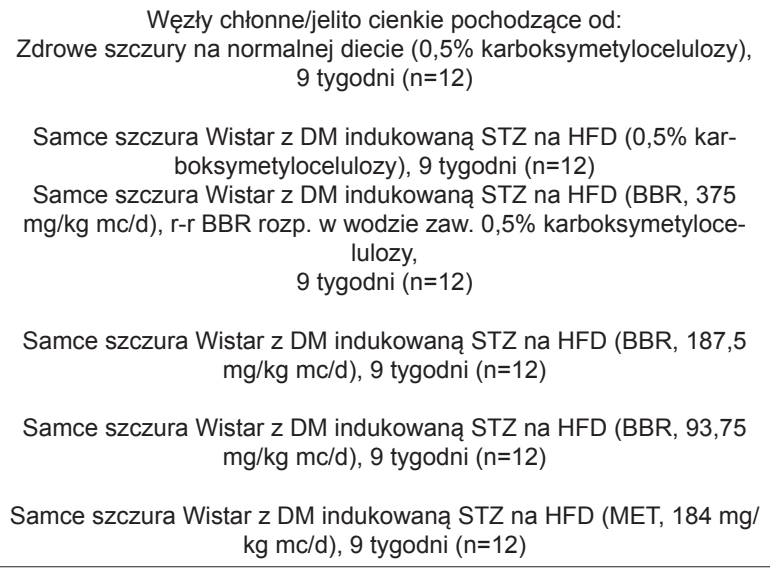 & $\begin{array}{c}\downarrow \text { liczby CD11b + CD68+ i \% } \uparrow \\
\text { makrofagów w węzłach chłonnych } \\
\text { krezkowych } \\
\% \uparrow \text { liczby limfocytów T regulato- } \\
\text { rowych (Treg) w węzłach chłonnych } \\
\text { krezkowych } \\
\downarrow \text { ekspresji IL-1ß, MIF i TNF-a mRNA } \\
\text { w jelicie } \\
\uparrow \\
\text { ekspresji IL-4 i IL-10 mRNA w jelicie } \\
\uparrow \text { ekspresji tzw. białek ,tight junction” } \\
\text { (połączeń ścisłych) - OCLN i ZO-1 } \\
\text { w jelicie } \\
\downarrow \text { ekspresji białka TLR4 i MyD88 } \\
\downarrow \text { fosforylacji IKKß (IKK2) } \\
\downarrow \text { LBP i CD14 mRNA w jelicie }\end{array}$ & [17] \\
\hline Zhang i wsp. & 2011 & $\begin{array}{l}\text { Mięśnie szkieletowe pochodzące od samców myszy KKay na HFD } \\
\text { z DM: } \\
\text { Grupa kontrolna - sól fizjologiczna }(250 \mathrm{mg} / \mathrm{kg} \mathrm{mc} / \mathrm{d}), 4 \text { tygodnie } \\
\qquad(\mathrm{n}=8)\end{array}$ & $\begin{array}{c}\uparrow \text { ekspresji genu GLUT-4, MAPK8, } \\
\text { MAPK14, PPAR } \alpha \text {, UCP2 i HNF-4a } \\
\downarrow \text { ekspresji genu PPAR } y, \text { CCAAT/ } \\
\text { CEBP, PGC i rezystyny }\end{array}$ & [18] \\
\hline Gomes i wsp. & 2012 & $\begin{array}{c}\text { Mysi mioblast szkieletowy } \mathrm{C} 2 \mathrm{C} 12 \\
\text { BBR (różne parametry = różne dawki = różny czas ekspozycji na } \\
\text { BBR) }\end{array}$ & $\begin{array}{c}\uparrow \text { aktywności SDH, COX, ATPazy i } \\
\text { syntazy cytrynianowej } \\
\uparrow \text { włókien mięśniowych typu IIA } \\
\text { (glikolityczno-tlenowych) } \\
\text { nieznaczne } \downarrow \text { włókien mięśniowych } \\
\text { typu IIB (glikolitycznych) } \\
\uparrow \text { wskaźnika NAD+/NADH }\end{array}$ & [19] \\
\hline
\end{tabular}




\begin{tabular}{|c|c|c|c|c|}
\hline Autor & Rok & Rodzaj badanego materiału & Efekt BBR $(p<0,05)$ & Piśmiennictwo \\
\hline Mi i wsp. & 2019 & $\begin{array}{l}\text { Podwzgórze/przysadka/mięśnie szkieletowe pochodzące od samców } \\
\qquad \begin{array}{c}\text { szczura Sprague-Dawley: } \\
\text { Zdrowe szczury na normalnej diecie, } 4 \text { tygodnie }(\mathrm{n}=9)\end{array} \\
\text { Szczury z DM indukowaną STZ na HFD (0,5\% karboksymetylocelu- } \\
\text { lozy, } 50 \mathrm{mg} / \mathrm{kg} \mathrm{mc} / \mathrm{d}), 4 \text { tygodnie }(\mathrm{n}=12) \\
\text { Szczury z DM indukowaną STZ na HFD (BBR, } 200 \mathrm{mg} / \mathrm{kg} \mathrm{mc/d}), 4 \\
\text { tygodnie ( } \mathrm{n}=12) \\
\text { Szczury z DM indukowaną STZ na HFD (MET, } 200 \mathrm{mg} / \mathrm{kg} \mathrm{mc/d}), 4 \\
\text { tygodnie ( } \mathrm{n}=12)\end{array}$ & $\begin{array}{c}\downarrow \text { poziomu oreksyny-A, OX2R i CRH } \\
\text { w podwzgórzu } \\
\downarrow \text { poziomu ACTH w przysadce } \\
\text { mózgowej } \\
\uparrow \text { ekspresji GLUT4 mRNA w } \\
\text { mięśniach szkieletowych }\end{array}$ & {$[20]$} \\
\hline Chen et al. & 2010 & $\begin{array}{l}\text { Adipocyty } 3 \mathrm{~T} 3-\mathrm{L} 1 \text { i miocyty } \mathrm{L} 6 \text { pochodzące od myszy } \mathrm{db} / \mathrm{db} \\
\text { BBR (różne parametry = różne dawki = różny czas ekspozycji na } \\
\text { BBR) }\end{array}$ & $\begin{array}{c}\uparrow \text { zdolności wychwytu glukozy przez } \\
\text { adipocyty 3T3-L1 i miocyty L6 } \\
\downarrow \text { aktywności PTP1B w adipocytach } \\
\text { 3T3-L1 } \\
\uparrow \text { fosforylacji InsR, IRS1 i PKB w } \\
\text { adipocytach 3T3-L1 }\end{array}$ & [21] \\
\hline Yang et al. & 2012 & $\begin{array}{c}\text { Preadipocyty pochodzące z tkanki tłuszczowej sieciowej (kompo- } \\
\text { nenta trzewnej tkanki tłuszczowej) pacjentów z MS }(n=9) \\
\operatorname{BBR}(0,0.1,1,10 \mu \mathrm{M})\end{array}$ & $\begin{array}{c}\downarrow \text { różnicowania preadipocytów } \\
\downarrow \text { ekspresji PPARy2, lipazy lipopro- } \\
\text { teinowej, C/EBPa, adiponektyny i } \\
\text { leptyny mRNA } \\
\downarrow \text { sekrecji leptyny i adiponektyny pod- } \\
\text { czas różnicowania preadipocytów }\end{array}$ & [22] \\
\hline Chang et al. & 2013 & $\begin{array}{l}\text { Komórki kardiomiocytów H9c2 pochodzące od szczurów z i bez IR } \\
\text { BBR }(5-20 \mu \mathrm{M}) ; 24 \text { h }\end{array}$ & $\begin{array}{c}\uparrow \text { podstawowego i stymulowanego } \\
\text { insuliną zużycia glukozy w komórkach } \\
\text { H9c2 z IR } \\
\text { aktywacja AMPK } \\
\uparrow \text { wskaźnika p-AMPK/AMPK }\end{array}$ & [23] \\
\hline
\end{tabular}

ACTH - hormon adrenokortykotropowy/kortykotropina (adrenocorticotropic hormone, corticotropin), AICAR - 5-aminoimidazolo-4-karboksyamid 1- $\beta$-D-rybofuranozyd (5-aminoimidazole-4-carboxamide 1 - $\beta$ - $D$-ribofuranoside), AMP - adenozyno-5'-monofosforan (adenosine monophosphate), AMPK - kinaza aktywowana 5'AMP (5)AMP-activated protein kinase), ATP - adenozyno-5'-trifosforan (adenosine triphosphate), BBR - berberyna (berberine), cAMP - cykliczny adenozyno-3',5'-monofosforan (3',5'- cyclic adenosine monophosphate), CCAAT/ CEBP - białko wiążące się z sekwencja CCAAT (CCAAT enhancer binding protein), CD - antygen różnicowania komórkowego, kompleks różnicowania (cluster of differentiation), ChREBP - białko wiążące sekwencję odpowiedzi na węglowodany (carbohydrate-responsive element-binding protein), COX - oksydaza cytochromu C (cytochrome C oxidase), CREB - białko wiążące element odpowiedzi na cAMP (cAMP response element-binding protein), CRH - hormon uwalniający kortykotropinę, kortykoliberyna, (corticotropin-releasing hormone, corticoliberin), DM - cukrzyca (diabetes mellitus), DPP-4 - dipeptydylopeptyza 4 (dipeptidyl peptidase 4), FAS - syntaza kwasów tłuszczowych (fatty acid synthase), FOXO1 - czynnik transkrypcyjny uczestniczący w regulacji glukoneogenezy i glikogenolizy oraz adipogenezy (forkhead box protein O1), GLP-1 - glukagonopodobny peptyd 1 (glucagon-like peptide-1), GLUT - transporter glukozy (glucose transporter), G6P - glukozo-6-fosforan (glucose-6-phosphate), HFD - dieta wysokotłuszczowa (high fat diet), HNF-4 $\alpha$ - wątrobowy czynnik jądrowy 4a (hepatic nuclear factor 4a), IKK $\beta$ (IKK2) - kinaza IKB (IKB kinase $\beta$ ), IL - interleukina (interleukin), InsR - receptor insuliny (insulin receptor), IR - insulinooporność (insulin restistance), IRS - substrat receptora insuliny (insulin receptor substrate), LBP - białko wiążące lipopolisacharyd (lipopolysaccharide binding protein), LKB1 - kinaza wątrobowa B1 (liver kinase B1), MAPK - kinaza białkowa aktywowane mitogenami (mitogen-activated protein kinase), MET - metformina (metformin), MIF - czynnik hamujący migrację makrofagów (macrophage migration inhibitory factor), mRNA - matrycowy RNA, rodzaj kwasu rybonukleinowego (messenger RNA), MS - zespół metaboliczny (metabolic syndrome), MyD88 - gen 88 pierwotnej odpowiedzi różnicowania szpiku (myeloid differentiation primary response gene 88), NADH - dinukleotyd nikotynoamidoadeninowy, forma zredukowana (nicotinamide adenine dinucleotide), NAD+ - dinukleotyd nikotynoamidoadeninowy, forma utleniona, NCD - zwyczajowa dieta (normal chow diet), OCLN - okludyna (occludin OX2R - receptor oreksyny typu 2 (orexin receptor type 2), p-AMPK - fosforylowana AMPK (phosphorylated AMPK), PC3 - konwertaza prohormonu 3 (prohormone convertase 3), PEPCK larboksykinaza fosfoenolopirogronianowa (phosphoenolpyruvate carboxykinase); PGC1 $\alpha$ - koaktywator PPAR1 $\alpha$ (PPAR $y$ coactivator $1 \alpha$ ), PKA - kinaza bialkowa A (protein kinase A), PKB - kinaza białkowa B (protein kinase B), PPAR - receptory aktywowane przez proliferatory peroksysomów (peroxisome proliferator-activated receptor), p-TORC2 - fosforylowany współczynnik transkrypcji regulowany przez CREB (phophorylated CREB regulated transcription coactivator 2), PTP-1B - białkowa fosfataza tyrozynowa (protein tyrosine phosphatase), SDH dehydrogenaza bursztynianowa (succinate dehydrogenase), SIRT - sirtuiny (sirtuins), SREBP - białko wiążące sterolowy element regulatorowy (sterol regulatory element-binding protein), STZ - streptozotocyna (streptozotocin), TG - triglicerydy (triglycerides), TLR4 - receptor Toll-podobny typu 4 (Toll-like receptor-4), TNF- $\alpha$ - czynnik martwicy nowotworu (tumor necrosis factor), UCP2 - rozprzęgacz protonów (uncoupling protein 2), ZO-1 - białko połączeń ścisłych (zonula occludens-1, tight junction protein-1). 
Kinaza aktywowana 5'AMP (5'AMP-activated protein kinase, AMPK) jest bardzo oszczędnym czujnikiem stanu energii komórkowej, który występuje u prawie wszystkich eukariontów. Po aktywacji AMPK promuje procesy kataboliczne (glikoliza, utlenianie kwasów tłuszczowych itp.), jednocześnie wyłączając szlak anaboliczny (synteza glikogenu, cholesterolu i białka itp.). Ekstrakt z korzenia B. mycrophylla ma działanie hipoglikemiczne i stymuluje wychwyt glukozy w komórkach HepG2 z i bez IR przez stymulację białka AMPK. W związku z tym uważa się, że aktywacja AMPK odpowiada za mechanizm działania BBR [11]. Ponadto BBR i MET promują metabolizm glukozy przez stymulowanie glikolizy - prawdopodobnie w wyniku hamowania mitochondrialnego kompleksu I łańcucha oddechowego w komórkach wątrobowych i mięśniowych, niezależnie od aktywacji AMPK [12].

Przez hamowanie deacetylazy sirtuiny BBR promuje wychwyt glukozy i hamuje glukoneogenezę oraz prowadzi do dysfunkcji mitochondriów i kumulacji adenozyno-5'monofosforanu (adenosine monophosphate, AMP) w hepatocytach myszy. Regulacja szlaków związanych z mitochondriami może być nowym podejściem do opracowywania leków przeciwcukrzycowych [24].

Badania sugerują, iż BBR może zmniejszać IR, częściowo także przez modulowanie mikrobioty jelitowej wraz $z$ hamowaniem sygnalizacji lipopolisacharyd (lipopolysaccharides, LPS) Toll-podobny receptor typu 4/ czynnik martwicy nowotworu a w wątrobie [14]. Zhong i wsp. wykazali, że BBR zmniejsza hiperglikemię przez hamowanie wątrobowego szlaku glukagonu u myszy z T2D [15]. Przypuszcza się, że hipoglikemiczne działanie BBR jest związane $z$ poprawą funkcjonowania hormonów jelitowych oraz zmniejszeniem mechanicznych uszkodzeń błony śluzowej jelit i bariery immunologicznej [17]. BBR wpływa hamująco na oś podwzgórze-przysadkanadnercza i zwiększa ekspresję białek - transporterów glukozy (glucose transporter 4,GLUT-4) w mięśniach szkieletowych samców szczura Sprague-Dawley. Może to być jednym z mechanizmów działania BBR w celu poprawy insulinowrażliwości oraz regulacji metabolizmu glukozy i lipidów w T2D [20].

$\mathrm{Na}$ podstawie badań Chen i wsp. dowiedli, że BBR naśladuje działanie insuliny przez wzrost zdolności do pobierania glukozy przez adipocyty 3T3-L1 i miocyty L6 w sposób niezależny od insuliny, hamując aktywność fosfatazy białkowo-tyrozynowej 1B, a zwiększając fosforylację InsR, substratu receptora insuliny i kinazy białkowej B w adipocytach 3T3-L1 [21].

Wyniki badania Chang i wsp. sugerują, że BBR poprawia insulinowrażliwość w komórkach kardiomiocytów częściowo przez stymulację aktywności AMPK [23].

\section{Badania in vivo na zwierzętach}

Ekstrakty z gatunków Berberis i ich składniki, zwłaszcza alkaloidy, zostały przebadane pod kątem potencjalnego wpływu na gospodarkę węglowodanową na modelach zwierzęcych in vivo. Wyniki wybranych badań przestawiono w tabeli 2.

Wykazano korzystny wpływ BBR na homeostaze glukozy i markery IR u samców szczurów Wistar z cukrzycą indukowaną streptozotocyną (streptozotocin, STZ) [25]. BBR znacznie poprawia funkcję mitochondriów w zwierzęcych i komórkowych modelach IR oraz T2D. Dane te wskazują także na rolę sirtuiny-1 i biogenezy mitochondriów w profilaktycznym działaniu BBR na IR indukowaną dietą [19]. Ponadto BBR moderuje metabolizm glukozy i lipidów poprzez mechanizm wielościeżkowy, który obejmuje szklaki, takie jak: AMPK-p38 MAPK (kinaza białkowa aktywowana mitogenami, mitogenactivated protein kinase) -GLUT-4, N-końcowe kinazy c-Jun/ kinazy aktywowane stresem oraz receptory aktywowane przez proliferatory peroksysomów a [18]. Mechanizmy odpowiedzialne za wyniki leczenia BBR mogą być związane z hamowaniem glukoneogenezy poprzez szlak sygnałowy kinazy wątrobowej B1 - współczynnika transkrypcji regulowanego przez CREB (CREB regulated transcription coactivator, TOCR2) [10]. Dowody $z$ badań in vivo $\mathrm{i}$ in vitro wskazują, że BBR tłumi aktywność disacharydaz i ekspresję mRNA kompleksu sacharaza-izomaltaza z korzystnymi wynikami metabolicznymi w stanach cukrzycowych. Działanie hamujące, przynajmniej częściowo, obejmuje szlak zależny od kinazy białkowej A [16]. Wykazano, że zastosowanie stałych nanocząsteczek lipidowych w celu zwiększenia absorpcji i biodostępności BBR, a osłabienia potencjalnych działań niepożądanych, wzmacnia również jej działanie przeciwcukrzycowe [26]. Równie korzystne wydaje się połączenie BBR z oligomerycznymi proantocyjanidynami, które należą do związków o silnych właściwościach przeciwutleniających. Kombinacja taka znacznie poprawia wchłanianie jelitowe i skuteczność hipoglikemicznej BBR [13]. Badacze dowiedli również, że BBR chroni przed kwasicą mleczanową związaną z leczeniem MET u szczurów z cukrzycą indukowaną STZ. Zaobserwowano również poprawę insulinowrażliwości i enzymów wątrobowych [27].

\section{Badania in vivo ludzi}

Istnieje niewiele badań oceniających zastosowanie BBR wśród ludzi. Badania pilotażowe, przedkliniczne i kliniczne, sugerują korzystne działanie wyciągów Berberis i izolowanych związków na T2D i inne choroby metaboliczne, co przedstawiono w tabeli 3 . 
Tabela 2. Wyniki wybranych badań in vivo przedstawiające potencjalne działanie berberyny przeciwko cukrzycy i innym chorobom metabolicznym

\begin{tabular}{|c|c|c|c|c|c|c|}
\hline Autor & Rok & Badana grupa & Dawka substancji oraz liczba zwierząt & $\begin{array}{c}\text { Czas } \\
\text { leczenia }\end{array}$ & Efekt $(p<0,05)$ & Piśmiennictwo \\
\hline $\begin{array}{l}\text { Yu i } \\
\text { wsp. }\end{array}$ & 2010 & $\begin{array}{l}\text { Zdrowe samce } \\
\text { szczura Sprague- } \\
\text { Dawley }\end{array}$ & $\begin{array}{l}\text { Grupa kontrolna - placebo } \\
\text { BBR } 60 \mathrm{mg} / \mathrm{kg} \mathrm{mc/d} \\
\text { BBR } 120 \mathrm{mg} / \mathrm{kg} \mathrm{mc/d}\end{array}$ & 5 tygodni & $\begin{array}{c}\downarrow \text { stężenia glukozy na czczo } \\
\downarrow \text { pobierania pokarmu } \\
\uparrow \text { wydzielania GLP-1 indukowane- } \\
\text { go obciążeniem glukozą } \\
\uparrow \text { ekspresję mRNA proglukagonu } \\
\text { w jelicie krętym w sposób zależny } \\
\text { od dawki } \\
\uparrow \text { proliferacji komórek L w jelicie }\end{array}$ & [3] \\
\hline $\begin{array}{l}\text { Chen i } \\
\text { wsp. }\end{array}$ & 2011 & $\begin{array}{c}\text { Samce szczura } \\
\text { Wistar }\end{array}$ & $\begin{array}{l}\text { Szczury z DM indukowaną STZ; BBR } 100 \mathrm{mg} \\
\text { mc/kg/d chlorek berberyny rozp. w wodzie } \\
\text { zaw. 0,5\% karboksymetylocelulozy }(n=7) \\
\text { Szczury z DM wywołaną STZ; 0,5\% karboksy- } \\
\text { metylocelulozy }(n=8) \\
\text { Grupa kontrolna - zdrowe szczury: } 0,5 \% \\
\text { karboksy-metylocelulozy }(n=10)\end{array}$ & 7 tygodni & $\begin{array}{c}\downarrow \text { stężenia glukozy na czczo i w } \\
\text { OGTT } \\
\downarrow \text { CRP } \\
\text { Hamowanie aktywności DPP-4 i } \\
\text { PTP-1B przez BBR }\end{array}$ & [25] \\
\hline $\begin{array}{l}\text { Gomes } \\
\text { i wsp. }\end{array}$ & 2012 & $\begin{array}{l}\text { Samce szczura } \\
\text { Sprague Dawley }\end{array}$ & $\begin{array}{c}\text { Standardowa dieta, } 12 \text { tygodni } \\
\text { HFD, } 12 \text { tygodni } \\
\text { HFD + BBR (100 mg/kg mc/d), } 4 \text { tygodnie }\end{array}$ & 4 tygodnie & $\begin{array}{c}\downarrow \text { masy ciała ogółem, FFM i FM } \\
\downarrow \text { stężenia insuliny na czczo } \\
\downarrow \text { stężenia leptyny } \\
\uparrow \text { stężenia adiponektyny } \\
\downarrow \text { wskaźnika leptyna/adiponektyna }\end{array}$ & [19] \\
\hline $\begin{array}{l}\text { Zhang i } \\
\text { wsp. }\end{array}$ & 2011 & $\begin{array}{l}\text { Otyłe samce } \\
\text { myszy KKay z DM } \\
\text { na HFD }\end{array}$ & $\begin{array}{l}\text { Grupa kontrolna - sól fizjologiczna: } 250 \mathrm{mg} / \\
\qquad \mathrm{kg} \mathrm{mc/d} \mathrm{(n=8)} \\
\text { BBR: } 250 \mathrm{mg} / \mathrm{kg} \mathrm{mc/d}(\mathrm{n}=8)\end{array}$ & 4 tygodnie & $\begin{array}{c}\downarrow \text { stężenia glukozy i insuliny na } \\
\text { czczo } \\
\downarrow \text { stężenia glukozy w OGTT } \\
\downarrow \downarrow \text { HOMA-IR }\end{array}$ & [18] \\
\hline $\begin{array}{l}\text { Jiang i } \\
\text { wsp. }\end{array}$ & 2015 & $\begin{array}{c}\text { Samce szczura } \\
\text { Wistar }\end{array}$ & $\begin{array}{l}\text { Grupa kontrolna - zdrowe szczury }(\mathrm{n}=8) \\
\text { Szczury z DM indukowaną STZ }(\mathrm{n}=8) \\
\text { Szczury z DM indukowaną STZ + BBR (156 } \\
\text { mg/kg mc/d), } 12 \text { tygodni }(\mathrm{n}=8) \\
\text { Szczury z DM indukowaną STZ + MET (184 } \\
\text { mg/kg mc/d), } 12 \text { tygodni ( } \mathrm{n}=8) \\
\text { Szczury z DM indukowaną STZ + AICAR (0.5 } \\
\text { mg/kg mc/d), } 12 \text { tygodni }(n=8)\end{array}$ & 12 tygodni & $\begin{array}{l}\downarrow \text { stężenia glukozy w OGTT } \\
\downarrow \text { stężenia insuliny na czczo } \\
\qquad \downarrow \text { HOMA-IR }\end{array}$ & [10] \\
\hline $\begin{array}{l}\text { Liu i } \\
\text { wsp. }\end{array}$ & 2010 & $\begin{array}{l}\text { Samce szczura } \\
\text { Sprague Dawley }\end{array}$ & 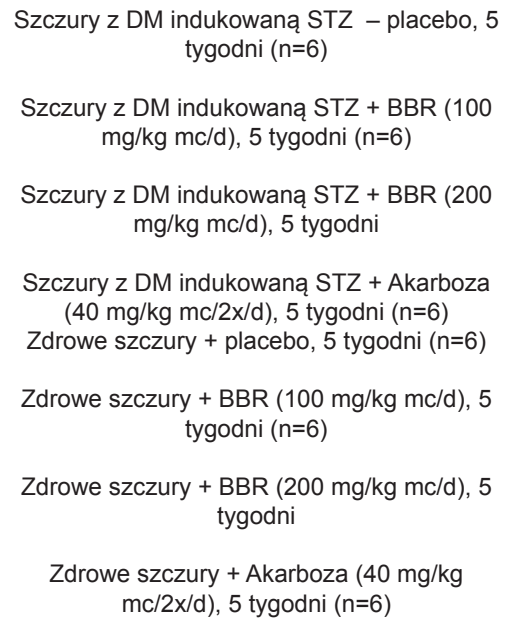 & 5 tygodni & $\begin{array}{c}\downarrow \text { aktywności disacharydaz w } \\
\text { jelicie } \\
\downarrow \text { ekspresji kompleksu sacharaza- } \\
\text { izomaltaza mRNA w jelicie } \\
\downarrow \text { przyjmowania pokarmu } \\
\downarrow \text { masy ciała } \\
\downarrow \text { stężenia glukozy i insuliny na } \\
\text { czczo } \\
\downarrow \text { poposiłkowego stężenia glukozy } \\
\text { we krwi po doustnym podaniu } \\
\text { sacharozy lub maltozy }\end{array}$ & {$[16]$} \\
\hline
\end{tabular}




\begin{tabular}{|c|c|c|c|c|c|c|}
\hline Autor & Rok & Badana grupa & Dawka substancji oraz liczba zwierząt & $\begin{array}{c}\text { Czas } \\
\text { leczenia }\end{array}$ & Efekt $(p<0,05)$ & Piśmiennictwo \\
\hline $\begin{array}{l}\text { Xue i } \\
\text { wsp. }\end{array}$ & 2013 & $\begin{array}{l}\text { Samce myszy db/ } \\
\text { db z DM }\end{array}$ & 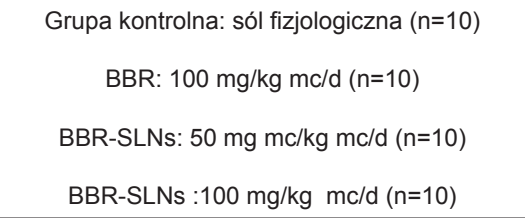 & 4 tygodnie & $\begin{array}{c}\downarrow \text { stężenia glukozy i insuliny na } \\
\text { CZczo } \\
\downarrow \text { HOMA-IR } \\
\downarrow \text { stężenia glukozy w IPGTT } \\
\downarrow \text { stężenia insuliny w IPITT }\end{array}$ & [26] \\
\hline $\begin{array}{l}\text { Zhang i } \\
\text { wsp. }\end{array}$ & 2018 & $\begin{array}{c}\text { Samce myszy db/ } \\
\text { db z DM }\end{array}$ & 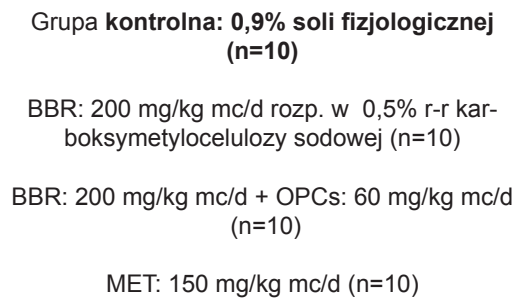 & 4 tygodnie & $\begin{array}{l}\downarrow \text { stężenia glukozy na czczo } \\
\downarrow \text { stężenia glukozy w OGTT } \\
\downarrow \text { stężenia insuliny w IPITT }\end{array}$ & [13] \\
\hline $\begin{array}{l}\text { Almani } \\
\text { et al. }\end{array}$ & 2017 & $\begin{array}{c}\text { Samce szczura } \\
\text { Wistar }\end{array}$ & 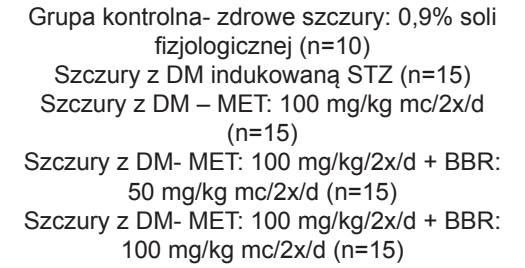 & $28 \mathrm{dni}$ & $\begin{array}{c}\downarrow \text { stężenia glukozy i insuliny na } \\
\text { czczo } \\
\downarrow \text { HbA1c } \\
\downarrow \text { HOMA-IR }\end{array}$ & [27] \\
\hline
\end{tabular}

AICAR - 5-aminoimidazolo-4-karboksyamid 1- $\beta$-D-rybofuranozyd (5-aminoimidazole-4-carboxamide 1- $\beta$ - $D$-ribofuranoside), BBR - berberyna (berberine), CRP - białko C-reaktywne (C-reactive protein), DM - cukrzyca (diabetes mellitus), DPP-4 - dipeptydylopeptyza 4 (dipeptidyl peptidase 4), HbA1c - hemoglobina glikowana A1c (glycated hemoglobin, hemoglobin A1c), FFM - beztłuszczowa masa ciała (free fat mass), FM - masa tkanki tłuszczowej (fat mass), HFD - dieta wysokotłuszczowa (high fat diet), IPGTT - dootrzewnowy test tolerancji glukozy (intraperitoneal glucose tolerance test), IPITT - dootrzewnowy test tolerancji insuliny (intraperitoneal insulin tolerance test), MET - metformina (metformin), mRNA - matrycowy RNA, rodzaj kwasu rybonukleinowego (messenger RNA), OGTT - doustny test obciążenia glukozą (oral glucose tolerance test), OPCs - oligomeryczne proantocyjanidyny (oligomeric proanthocyanidins), PTP-1B - białkowa fosfataza tyrozynowa (protein tyrosine phosphatase), SLNs - stałe nanocząsteczki lipidowe (solid lipid nanoparticles), STZ - streptozotocyna (streptozotocin)

Tabela 3. Wyniki wybranych badań klinicznych przedstawiające potencjalne działanie berberyny przeciwko cukrzycy i innym chorobom metabolicznym

\begin{tabular}{|c|c|c|c|c|c|c|}
\hline Autor & Rok & Badana grupa & $\begin{array}{l}\text { Liczba pacjentów oraz dawka } \\
\text { substancji }\end{array}$ & $\begin{array}{c}\text { Czas } \\
\text { leczenia }\end{array}$ & Efekt $(p<0,05)$ & Piśmiennictwo \\
\hline $\begin{array}{l}\text { Yang i } \\
\text { wsp. }\end{array}$ & 2012 & Pacjenci z MS & BBR; 0,3 g 3x/d $(n=37)$ & $\begin{array}{c}3 \\
\text { miesiące }\end{array}$ & $\begin{array}{c}\downarrow \text { BMI } \\
\downarrow \text { obwodu talii } \\
\downarrow \text { TG } \\
\downarrow \text { stężenia glukozy i insuliny na czczo } \\
\downarrow \text { HOMA-IR } \\
\downarrow \text { HbA1c } \\
\downarrow \text { leptyny } \\
\downarrow \text { wskaźnika leptyna/adiponektyna }\end{array}$ & [22] \\
\hline $\begin{array}{l}\text { Perez- } \\
\text { Rubio i } \\
\text { wsp. }\end{array}$ & 2013 & Pacjenci z MS & $\begin{array}{c}\text { BBR } 0,5 \text { g } 3 x / d(n=12) \\
\text { placebo }(n=12)\end{array}$ & $\begin{array}{c}3 \\
\text { miesiące }\end{array}$ & $\begin{array}{c}\downarrow \text { BMI } \\
\downarrow \text { obwodu talii } \\
\downarrow \text { stężenia glukozy na czczo } \\
\downarrow \text { AUC glukozy } \\
\downarrow \text { AUC insuliny } \\
\downarrow \text { insulinogenic index } \\
\uparrow \text { wskaźnika Matsudy }\end{array}$ & [28] \\
\hline $\begin{array}{l}\text { Chen i } \\
\text { wsp. }\end{array}$ & 2016 & Pacjenci z T2D & BBR: $0,3 \mathrm{~g} / 3 \mathrm{x} / \mathrm{d}(\mathrm{n}=30)$ & 8 tygodni & $\begin{array}{c}\downarrow \text { BMI } \\
\downarrow \text { stężenia glukozy i insuliny na czczo } \\
\downarrow \text { HbA1c } \\
\downarrow \text { ekspresji TNF-a, CRP i LPS, } \\
\uparrow \text { Bifidobacterium ogółem, B. longum, B. } \\
\text { breve, B. adolescentis w kale }\end{array}$ & [29] \\
\hline
\end{tabular}




\begin{tabular}{|c|c|c|c|c|c|c|}
\hline Autor & Rok & Badana grupa & $\begin{array}{l}\text { Liczba pacjentów oraz dawka } \\
\text { substancji }\end{array}$ & $\begin{array}{c}\text { Czas } \\
\text { leczenia }\end{array}$ & Efekt $(p<0,05)$ & Piśmiennictwo \\
\hline $\begin{array}{l}\text { Memon i } \\
\text { wsp. }\end{array}$ & 2018 & Pacjenci z T2D & $\begin{array}{l}\text { BBR; } 0,5 \text { g 3x/d }(n=100) \\
\text { MET; } 0,5 \text { g 3x/d ( } n=100)\end{array}$ & $\begin{array}{c}3 \\
\text { miesiące }\end{array}$ & $\begin{array}{c}\downarrow \text { masy ciała } \\
\downarrow \text { stężenia glukozy i insuliny na czczo } \\
\downarrow \text { HbA1c } \\
\downarrow \text { HOMA-IR } \\
\downarrow \text { stężenia metyloglioksalu }\end{array}$ & [30] \\
\hline $\begin{array}{l}\text { Sheng i } \\
\text { Xie }\end{array}$ & 2010 & Pacjenci z T2D & $\begin{array}{l}\text { BBR: } 0,5 \mathrm{~g} 3 x / \mathrm{d}+\mathrm{MET}: 0,5 \mathrm{~g} 3 \mathrm{x} / \mathrm{d}+ \\
\text { glipizyd: } 5 \mathrm{mg} 2 \mathrm{x} / \mathrm{d}(\mathrm{n}=30) \\
\text { MET: } 0,5 \mathrm{~g} 3 \mathrm{x} / \mathrm{d}+\text { glipizyd: } 5 \mathrm{mg} 2 \mathrm{x} / \mathrm{d} \\
(\mathrm{n}=30)\end{array}$ & $\begin{array}{c}3 \\
\text { miesiące }\end{array}$ & 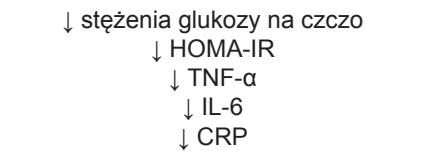 & [31] \\
\hline \multirow[t]{2}{*}{$\begin{array}{l}\text { Zhang i } \\
\text { wsp. }\end{array}$} & 2010 & Pacjenci z T2D & $\begin{array}{l}\text { BBR: } 0,5 \mathrm{~g} / 2 \mathrm{x} / \mathrm{d}(\mathrm{n}=50) \\
\text { MET: } 0,75 \mathrm{~g} / 2 \mathrm{x} / \mathrm{d}(\mathrm{n}=26) \\
\text { Rozyglitazon: } 4 \mathrm{mg} / \mathrm{d}(\mathrm{n}=21)\end{array}$ & $\begin{array}{c}2 \\
\text { miesiące }\end{array}$ & 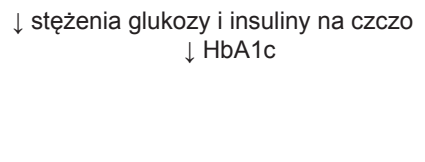 & [4] \\
\hline & & $\begin{array}{l}\text { Pacjenci z T2D/ IFG } \\
\text { i WZWB/WZWC }\end{array}$ & BBR: $1 \mathrm{~g} / \mathrm{d}(\mathrm{n}=35)$ & & $\downarrow$ stężenia glukozy na czczo & \\
\hline Cao i Su & 2019 & Pacjenci z MS & $\begin{array}{l}\text { BBR } 4 \text { tabl. } 3 x / d(n=40) \\
\text { Tradycyjna farmakoterapia MS }(n=40)\end{array}$ & $\begin{array}{c}1 \\
\text { miesiąc }\end{array}$ & $\begin{array}{c}\downarrow \text { stężenia glukozy na czczo } \\
\downarrow \text { poposiłkowego stężenia glukozy } \\
\downarrow \text { HOMA-IR } \\
\downarrow \text { hs-CRP } \\
\downarrow \text { IL-6 } \\
\downarrow \text { TNF- } \alpha\end{array}$ & [32] \\
\hline $\begin{array}{l}\text { Shidfar i } \\
\text { wsp. }\end{array}$ & 2012 & Pacjenci z T2D & $\begin{array}{c}\text { Ekstrakt z owoców Berberis vul- } \\
\text { garis (BBR); } 3 \mathrm{~g}-0,5 \mathrm{~g} \mathrm{3x/d}(\mathrm{n}=21) \\
\text { Placebo - laktoza }(\mathrm{n}=21)\end{array}$ & $\begin{array}{c}3 \\
\text { miesiące }\end{array}$ & $\begin{array}{c}\downarrow \text { stężenia glukozy i insuliny na czczo } \\
\downarrow \downarrow \text { HOMA-IR }\end{array}$ & [33] \\
\hline $\begin{array}{l}\text { Di Pierro } \\
\text { i wsp. }\end{array}$ & 2012 & Pacjenci z T2D & $\begin{array}{c}\text { Berberol }{ }^{\circledR} \text { (Berberis aristata, berberys } \\
\text { indyjski }-0,5 \mathrm{~g} \text { BBR oraz Sylibum } \\
\text { marianum, sylimaryna }-105 \mathrm{mg}) 2 \mathrm{x} / \mathrm{d} \\
(\mathrm{n}=22)\end{array}$ & $\begin{array}{c}6 \\
\text { miesięcy }\end{array}$ & $\begin{array}{c}\downarrow \text { HbA1c } \\
\downarrow \text { stężenia insuliny na czczo } \\
\downarrow \text { HOMA-IR }\end{array}$ & [34] \\
\hline $\begin{array}{l}\text { Derosa i } \\
\text { wsp. }\end{array}$ & 2013 & $\begin{array}{l}\text { Pacjenci z nadwagą } \\
\text { i dyslipidemią o nis- } \\
\text { kim ryzyku sercowo- } \\
\text { naczyniowym }\end{array}$ & $\begin{array}{l}\text { Berberol }{ }^{\circledR} 2 \mathrm{x} / \mathrm{d} \\
\text { Placebo }\end{array}$ & $\begin{array}{c}3 \\
\text { miesiące }\end{array}$ & $\begin{array}{l}\downarrow \text { stężenia insuliny na czczo } \\
\quad \downarrow \text { HOMA-IR } \\
\downarrow \text { stężenia rezystyny i RBP-4 } \\
\uparrow \text { stężenia adiponektyny }\end{array}$ & [35] \\
\hline $\begin{array}{l}\text { Di Pierro } \\
\text { i wsp. }\end{array}$ & 2015 & $\begin{array}{l}\text { Pacjenci z T2D i } \\
\text { hipercholesterolemią } \\
\text { nietolerujący statyn }\end{array}$ & 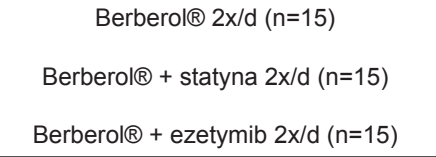 & $\begin{array}{c}12 \\
\text { miesięcy }\end{array}$ & $\begin{array}{c}\downarrow \text { stężenia glukozy na czczo } \\
\qquad \mathrm{HbA} 1 \mathrm{c}\end{array}$ & [36] \\
\hline $\begin{array}{l}\text { Guarino i } \\
\text { wsp. }\end{array}$ & 2017 & Pacjenci z MS & $\begin{array}{l}\text { Berbero|® 2x/d (n=68) } \\
\text { Placebo } 2 x / d(n=68)\end{array}$ & $\begin{array}{l}52 \text { ty- } \\
\text { godnie }\end{array}$ & $\begin{array}{c}\downarrow \text { HOMA-IR } \\
\downarrow \text { obwodu talii } \\
\downarrow \text { oTF } \\
\downarrow \% \text { VF } \\
\downarrow \text { HbA1c }\end{array}$ & [37] \\
\hline
\end{tabular}

AUC - pole pod krzywą (area under the curve), BBR - berberyna (berberine), BMI - wskaźnik masy ciała (body mass index), CRP - białko C-reaktywne (C-reactive protein), HbA1c - hemoglobina glikowana A1c (glycated hemoglobin, hemoglobin A1c), hs-CRP wysokoczułe CRP (high-sensitivity CRP), IFG - nieprawidłowa glikemia na czczo (impaired fasting glucose), IL - interleukina (interleukin), LPS - lipopolisacharyd (lipopolysaccharides), MET - metformina (metformin), MS - zespół metaboliczny (metabolic syndrome), RBP-4 - białko wiążące retinol typu 4 (retinol-binding protein 4), T2D - cukrzyca typu 2 (type 2 diabetes), TF - całkowita zawartość tłuszczu (total fat), TG - triglicerydy (triglycerides), TNF- $\boldsymbol{\alpha}$ - czynnik martwicy nowotworu (tumor necrosis factor), VF - tłuszcz trzewny (visceral fat), WZW - wirusowe zapalenie wątroby (viral hepatitis)

Suplementacja BBR może poprawiać wrażliwość na insulinę przez hamowanie magazynowania tłuszczu i modyfikację profilu adipocytokin w ludzkich preadipocytach u pacjentów z zespołem metabolicznym (metabolic syndrome, MS) [22]. Podawanie BBR, w porównaniu z placebo, prowadziło do remisji zespołu metabolicznego oraz wzrostu wrażliwości na insulinę w wyniku zmniejszenia: obwodu talii, skurczowego ciśnienia krwi, triglicerydów i całkowitego wydzielania insuliny [28]. Nowe dane naukowe wskazują na istotny udział mikrobioty jelitowej w rozwoju T2D. Tezę tę potwierdzają Chen i wsp., którzy wykazali poprawę parametrów gospodarki węglowodanowej i 
lipidowej w wyniku modulacji Bifidobacterium, TNF-a i LPS po zastosowaniu 8-tygodniowej suplementacji BBR u pacjentów z T2D [29]. W porównaniu z MET, BBR skuteczniej obniżała poziom metyloglikosalu, będącego zaawansowanym produktem glikacji, w surowicy i IR przez lepszą kontrolę glikemii u nowo zdiagnozowanych pacjentów z T2D [30]. Badanie Sheng i Xie wykazało znaczące korzyści zdrowotne z dołączenia suplementacji BBR do tradycyjnej farmakoterapii T2D obejmującej MET i glipizyd. U pacjentów zaobserwowano redukcję: stężenia glukozy na czczo, insulinooporności, TNF- $\alpha$, interleukiny- 6 oraz białka C-reaktywnego [31]. Natomiast Zhang i wsp. dowiedli, że skuteczność BBR w obniżaniu m.in. stężenia glukozy na czczo oraz poziomu hemoglobiny glikowanej była podobna do skuteczności MET i rozyglitazonu w T2D. Zaobserwowano również poprawę parametrów metabolicznych u pacjentów z T2D, nieprawidłową glikemią na czczo oraz wirusowym zapaleniem wątroby typu B i C [4]. Natomiast w innym badaniu porównującym suplementację BBR z tradycyjną farmakoterapią MS stwierdzono, że BBR skuteczniej reguluje poziom glukozy i lipidów we krwi, poprawia IR oraz zmniejsza poziom odpowiedzi zapalnych w organizmie u pacjentów z MS [32]. Trzymiesięczna codzienna podaż $3 \mathrm{~g}$ wyciągu z owoców $B$. vulgaris może korzystnie wpływać na parametry gospodarki lipidowej, węglowodanowej oraz całkowitą pojemność antyoksydacyjną u pacjentów z T2D [33]. Natomiast sześciomiesięczna suplementacja preparatem Berberol $^{\circledR}$, zawierającym ekstrakt z B. aristata oraz $S$. marianum, miała pozytywny wpływ na parametry glikemiczne i lipidowe u osób chorujących na T2D [34]. Skuteczność tego preparatu nutraceutycznego w poprawie parametrów metabolicznych, w tym m.in. IR, zbadano kilkukrotnie [35, 36, 37].

Metaanaliza i przegląd systemowy dziewięciu randomizowanych badań kontrolnych wykazała obiecującą rolę BBR u pacjentek z zespołem policystycznych jajników z insulinoopornością. Nie stwierdzono jednak istotnej różnicy między BBR a MET w łagodzeniu IR, poprawie metabolizmu węglowodanów i lipidów oraz zaburzeniach układu rozrodczego. MET w połączeniu z BBR nie wykazała lepszych wyników niż sama MET. Konieczne są dalsze bardziej szczegółowe badania w celu potwierdzenia działania i bezpieczeństwa BBR w przebiegu zespołu policystycznych jajników z insulinoopornością [38].

\section{Podsumowanie}

Na podstawie wyników licznych badań in vitro i in vivo wydaje się, że BBR może potencjalnie doskonale uzupełniać leczenie niefarmakologiczne IR czy T2D. Jednak dotychczasowe badania prowadzono głównie in vitro lub na modelu zwierzęcym, a ich stopień wiarygodności jest niski. Wobec tego potrzebne są dobrze zaprojektowane, wieloośrodkowe randomizowane badania kliniczne, w celu ocenienia wpływu BBR na gospodarkę węglowodanową, ustalenia dawki terapeutycznej oraz potencjalnych działań niepożądanych.

\section{Konflikt interesów}

Autorzy deklarują brak potencjalnych konfliktów interesów.

\section{Piśmiennictwo}

[1] Rad S.Z., Rameshrad M., Hosseinzadeh H.: Toxicology effects of Berberis vulgaris (barberry) and its active constituent, berberine: A review. Iran J. Basic. Med. Sci., 2017; 20: 516-529

[2] Wojciechowska I.: Berberys pospolity - roślina ozdobna i lecznicza. Kosmos. Problemy Nauk Biol., 2017; 66: 487-490

[3] Yu Y., Liu L., Wang X., Liu X., Liu X., Xie L., Wang G.: Modulation of glucagon-like peptide-1 release by berberine: in vivo and in vitro studies. Biochem. Pharmacol., 2010; 79: 1000-1006

[4] Zhang H., Wei J., Xue R., Wu J.D., Zhao W., Wang Z.Z., Wang S.K., Zhou Z.X., Song D.Q., Wang Y.M. i wsp.: Berberine lowers blood glucose in type 2 diabetes mellitus patients through increasing insulin receptor expression. Metabolism, 2010; 59: 285-292

[5] Xing L.J., Zhang L., Liu T., Hua Y.Q., Zheng P.Y., Ji G.: Berberine reducing insulin resistance by up-regulating IRS-2 mRNA expression in non-alcoholic fatty liver disease (NAFLD) rat liver. Eur. J. Pharmacol., 2011; 668: 467-471

[6] Xia X., Yan J., Shen Y., Tang K., Yin J., Zhang Y., Yang D., Liang $\mathrm{H}$., Ye J., Weng J.: Berberine improves glucose metabolism in diabetic rats by inhibition of hepatic gluconeogenesis. PLoS One, 2011; 6: e16556

[7] Abd El-Wahab A.E., Ghareeb D.A., Sarhan E.E., Abu-Serie M.M., El Demellawy M.A.: In vitro biological assessment of Berberis vulgaris and its active constituent, berberine: Antioxidants, antiacetylcholinesterase, anti-diabetic and anticancer effects. BMC Complement. Altern. Med., 2013; 13: 218

[8] Boudjelthia K., Hammadi K., Kouidri M., Djebli N.: Evaluation of antidiabetic activity of two plants Berberis vulgaris and ZygophylIum geslini. J. Phys. Chem. Biophys., 2017; 7: 236

[9] Chakrabarti R., Bhavtaran S., Narendra P., Varghese N., Vanchhawng L., Shihabudeen M.S., Thirumurgan K.: Dipeptidyl peptidase-IV inhibitory activity of Berberisaristata. J. Nat. Prod., 2011; 4: 158-163

[10] Jiang S.J., Dong H., Li J.B., Xu L.J., Zou X., Wang K.F., Lu F.E., Yi P.: Berberine inhibits hepatic gluconeogenesis via the LKB1AMPK-TORC2 signaling pathway in streptozotocin-induced diabetic rats. World J. Gastroenterol., 2015; 21: 7777-7785 
[11] Furrianca M.C., Alvear M., Zambrano T., Fajardo V., Salazar L.A.: Hypoglycemic effect of Berberis microphylla G Forst root extract. Trop. J. Pharm. Res., 2017; 16: 2179-2184

[12] Xu M., Xiao Y., Yin J., Hou W., Yu X., Shen L., Liu F., Wei L., Jia W.: Berberine promotes glucose consumption independently of AMP-activated protein kinase activation. PLoS One, 2014; 9 : e103702

[13] Zhang H., Wang X., Wang T., Chen K., Wang H., Jia Q., Li Y.: Enhancement of berberine hypoglycemic activity by oligomeric proanthocyanidins. Molecules, 2018; 23: 3318

[14] Liu D., Zhang Y., Liu Y., Hou L., Li S., Tian H., Zhao T.: Berberine modulates gut microbiota and reduces insulin resistance via the TLR4 signaling pathway. Exp. Clin. Endocrinol. Diabetes, 2018; 126: $513-520$

[15] Zhong Y., Jin J., Liu P., Song Y., Zhang H., Sheng L., Zhou H., Jiang B.: Berberine attenuates hyperglycemia by inhibiting the hepatic glucagon pathway in diabetic mice. Oxid. Med. Cell. Longev., 2020; 2020: 6210526

[16] Liu L., Yu Y.L., Yang J.S, Li Y., Liu Y.W., Liang Y., Liu X.D., Xie L., Wang G.J.: Berberine suppresses intestinal disaccharidases with beneficial metabolic effects in diabetic states, evidences from in vivo and in vitro study. Naunyn. Schmiedebergs. Arch. Pharmacol., 2010; 381: 371-381

[17] Gong J., Hu M., Huang Z., Fang K., Wang D., Chen Q., Li J., Yang D., Zou X., Xu L. i wsp.: Berberine attenuates intestinal mucosal barrier dysfunction in type 2 diabetic rats. Front Pharmacol., 2017; 8: 42

[18] Zhang Q., Xiao X., Feng K., Wang T., Li W., Yuan T., Sun X., Sun Q., Xiang $\mathrm{H}$., Wang $\mathrm{H}$.: Berberine moderates glucose and lipid metabolism through multipathway mechanism. Evid. Based Complement. Alternat. Med., 2011; 2011: 924851

[19] Gomes A.P., Duarte F.V., Nunes P., Hubbard B.P., Teodoro J.S., Varela A.T., Jones J.G., Sinclair D.A., Palmeira C.M., Rolo A.P.: Berberine protects against high fat diet-induced dysfunction in muscle mitochondria by inducing SIRT1-dependent mitochondrial biogenesis. Biochem. Biophys. Acta, 2012; 1822: 185-195

[20] Mi J., He W., Lv J., Zhuang K., Huang H., Quan S.: Effect of berberine on the HPA-axis pathway and skeletal muscle GLUT4 in type 2 diabetes mellitus rats. Diabetes Metab. Syndr. Obes., 2019; 12: $1717-1725$

[21] Chen C., Zhang Y., Huang C.: Berberine inhibits PTP1B activity and mimics insulin action. Biochem. Biophys. Res. Commun., 2010; 397: 543-547

[22] Yang J., Yin J., Gao H., Xu L., Wang Y., Xu L., Li M.: Berberine improves insulin sensitivity by inhibiting fat store and adjusting adipokines profile in human preadipocytes and metabolic syndrome patients. Evid. Based Complement. Alternat. Med., 2012; 2012: 363845

[23] Chang W., Zhang M., Li J., Meng Z., Wei S., Du H., Chen L., Hatch G.M.: Berberine improves insulin resistance in cardiomyocytes via activation of 5'-adenosine monophosphate-activated protein kinase. Metabolism, 2013; 62: 1159-1167
[24] Zhang B., Pan Y., Xu L., Tang D., Dorfman R.G., Zhou Q., Yin Y., Li Y., Zhou L., Zhao S. i wsp.: Berberine promotes glucose uptake and inhibits gluconeogenesis by inhibiting deacetylase SIRT3. Endocrine, 2018; 62: 576-587

[25] Chen Y., Wang Y., Zhang J., Sun C., Lopez A.: Berberine improves glucose homeostasis in streptozotocin-induced diabetic rats in association with multiple factors of insulin resistance. ISRN Endocrinol., 2011; 2011: 519371

[26] Xue M., Yang M.X., Zhang W., Li X.M., Gao D.H., Ou Z.M., Li Z.P., Liu S.H., Li X.J., Yang S.Y.: Characterization, pharmacokinetics, and hypoglycemic effect of berberine loaded solid lipid nanoparticles. Int. J. Nanomedicine, 2013; 8: 4677-4687

[27] Almani S.A., Memon I.A., Shaikh T.Z., Khoharo H.K., Ujjan I.: Berberine protects against metformin-associated lactic acidosis in induced diabetes mellitus. Iran J. Basic Med. Sci., 2017; 20: 511-515

[28] Pérez-Rubio K.G., González-Ortiz M., Martínez-Abundis E., Robles-Cervantes J.A., Espiinel-Bermúdez M.C.: Effect of berberine administration on metabolic sydrome, insulin sensitivity, and insulin secretion. Metab. Syndr. Relat. Disord., 2013; 11: 366-369

[29] Chen L, Lu W, Li Y. Berberine ameliorates type 2 diabetes via modulation of Bifidobacterium species, tumor necrosis factor- $\alpha$, and lipopolysaccharide. Int. J. Clin. Exp. Med., 2016; 9: 9365-9372

[30] Memon M.A., Khan R.N., Riaz S., Ain Q.U., Ahmed M., Kumar $\mathrm{N}$.: Methylglyoxal and insulin resistance in berberine-treated type 2 diabetic patients. J. Res. Med. Sci., 2018; 23: 110

[31] Sheng Z.X., Xie D.H.: Therapeutic effect of berberine on the levels of inflammatory factors in type 2 diabetic patients. New Med., 2010; 4: 177-180

[32] Cao C., Su M.: Effects of berberine on glucose-lipid metabolism, inflammatory factors and insulin resistance in patients with metabolic syndrome. Exp. Ther. Med., 2019; 17: 3009-3014

[33] Shidfar F., Ebrahimi S.S., Hosseini S., Heydari I., Shidfar S., Hajhassani G.: The effects of Berberis vulgaris fruit extract on serum lipoproteins, apoB, apoA-I, homocysteine, glycemic control and total antioxidant capacity in type 2 diabetic patients. Iran J. Pharm. Res., 2012; 11: 643-652

[34] Di Pierro F., Villanova N., Agostini F., Marzocchi R., Soverini V., Marchesini G.: Pilot study on the additive effects of berberine and oral type 2 diabetes agents for patients with suboptimal glycemic control. Diabetes Metab. Syndr. Obes., 2012; 5: 213-217

[35] Derosa G., Bonaventura A., Bianchi L., Romano D., D’Angelo A., Fogari E., Maffioli P.: Effects of Berberis aristata/Silybum marianum association on metabolic parameters and adipocytokines in overweight dyslipidemic patients. J. Biol. Regul. Homeost. Agents, 2013; 27: 717-728

[36] Di Pierro F., Bellone I., Rapacioli G., Putignano P.: Clinical role of a fixed combination of standardized Berberis aristata and Silybum marianum extracts in diabetic and hypercholesterolemic patients intolerant to statins. Diabetes Metab. Syndr. Obes., 2015; 8: 89-96

[37] Guarino G., Strollo F., Carbone L., Della Corte T., Letizia M., Marino G., Gentile S.: Bioimpedance analysis, metabolic effects and 
safety of the association Berberis aristata/Silybum marianum: A 52-week double-blind, placebo-controlled study in obese patients with type 2 diabetes. J. Biol. Regul. Homeost. Agents, 2017; 31: 495-502

[38] Li M.F., Zhou X.M., Li X.L.: The effect of berberine on polycystic ovary syndrome patients with insulin resistance (PCOS-IR): A meta-analysis and systematic review. Evid. Based Complement Alternat. Med., 2018; 2018: 2532935 